\title{
The association between body composition, physical activity, and body image among Costa Rican models and controls
}

\author{
Yamileth CHACÓN-ARAYA ${ }^{1,2}$, Isaura CASTILLO-HERNÁNDEZ ${ }^{1,3}$ \\ Y José MONCADA-JIMÉNEZ ${ }^{1}$ \\ ${ }^{1}$ University of Costa Rica, Costa Rica \\ ${ }^{2}$ University Pablo de Olavide, Spain \\ ${ }^{3}$ University of Georgia, United States of America
}

(Received on December 16, 2017; Accepted on July 25, 2018)

\begin{abstract}
The aim of the study was to determine the association between body composition, physical activity and body image (BI) among Costa Rican models and controls. Participants were female $(n=35)$ and male $(n=18)$ models and female $(n=40)$ and male $(n=42)$ controls. Participants underwent body composition assessments, completed the International Physical Activity Questionnaire and gender-specific BI scales. Body fat \% (BF\%) was lower in models than controls and lower in males than females $(p \leq 0.001)$. BI was similar between female models and controls and between male models and controls. Males showed higher physical activity (PA) levels than females $(p=0.001)$. Significant correlations were found between weekly PA and BF\% $(p \leq 0.001)$. In conclusion, Costa Rican models are taller and presented lower BF\% than controls. Males were more physically active than females and BI perception was similar between genders and groups.
\end{abstract}

Keywords: Body Image, Models, Body Composition, Hispanics, Costa Rica, Physical Activity, Body Satisfaction.

\section{La asociación entre la composición corporal, la actividad física, y la imagen corporal en modelos y controles costarricenses}

RESUMEN: El propósito del estudio fue determinar la asociación entre la composición corporal, la actividad física y la imagen corporal (IC) en modelos y controles costarricenses. Participaron modelos femeninas $(n=35)$ y masculinos $(n=18)$ y controles femeninas $(n=40)$ y masculinos $(n=42)$. A los participantes se les evaluó la composición corporal y llenaron el Cuestionario Internacional de Actividad Física y escalas de IC específicas por sexo. El \% de grasa corporal (\%GC) fue menor en los modelos que en los controles y menor en hombres que en mujeres $(p \leq 0.001)$. La IC fue similar entre modelos femeninas y controles y entre hombres modelos y controles. Los hombres mostraron mayor actividad física $(\mathrm{AF})$ que las mujeres $(p=0.001)$. Se encontraron correlaciones significativas entre la cantidad de AF semanal y el \%GC $(p \leq 0.001)$. Se concluye que los modelos costarricenses son más altos y tienen menos \%GC que los controles. Los hombres son físicamente más activos que las mujeres y la percepción de IC es similar entre sexos y grupos. 
Palabras claves: Imagen corporal, modelaje, composición corporal, hispanos, Costa Rica, actividad física, satisfacción corporal.

Address for correspondence: José Moncada-Jiménez, Ph.D. Human Movement Sciences Research Center (CIMOHU), University of Costa Rica. P.O. Box 239-1200 Pavas, San Jose, Costa Rica. Tel. +506 2511-2909. E-mail: jose.moncada@ucr.ac.cr

\section{Introduction}

The modeling industry, like any other business, depends on its workers to achieve economic goals. Model scouts look for stereotypical female and male youngsters in order to recruit them for this industry, promising a celebrity status, glory, and fortune. It has been reported that female models earn salaries of approximately $\$ 32,000 /$ year with no benefits (Cline, 2013). In this context, physically attractive features such as being tall and having a slender, fit, and muscular body, as well as overall good looks (e.g., facial and sexual attractiveness) are key for models constantly appearing on fashion runways and in the media; however, some of these features are at odds with good health. For instance, new laws and modeling agencies have banned female models from fashion shows if their body mass index (BMI = body weight $[\mathrm{kg}] /$ body height $\left[\mathrm{m}^{2}\right]$ ) is $<18 \mathrm{~kg} / \mathrm{m}^{2}$ (Stableford, 2012). A low BMI has been related to several physical, metabolic, and psychological diseases (Berlinger \& Potter, 1991; De Laet et al., 2005; Kremers, Nicola, Crowson, Ballman, \& Gabriel, 2004; Liu et al., 2015; Ravn et al., 1999). BMI is a surrogate marker of body adiposity commonly used in epidemiological studies. Although related to body composition, the BMI does not always relate to body fat mass; a better indicator of a person's body composition and disease risk predictor (American College of Sports Medicine, 2010, 2014). There is a dearth of studies describing models' body composition using state-of-the-art or gold standard devices, such as dual energy X-ray absorptiometry (DXA). Although DXA provides valid and reliable information not only about body composition (e.g., total and regional fat mass) but also on bone mineral density (BMD), a marker of bone health, it is also known that it has an elevated cost and requires highly trained technicians for data acquisition (Nana, Slater, Stewart, \& Burke, 2015).

Increased levels of physical activity (PA) are related to a healthy body composition profile (i.e., reduced body fat mass, increased muscle mass) and disease risk reduction (Ekelund et al., 2011). International organizations have defined PA as any bodily movement produced by skeletal muscles that requires energy expenditure (Garber et al., 2011). There is no scientific literature describing the PA levels of models; however, in males, there is social pressure to perform PA that promotes an appearance of strength and power, and for females, PA is aimed at achieving a slender and toned body (Fanjul-Peyró \& González-Oñate, 2011; Kim \& Sagas, 2014). Unfortunately, this pressure might lead to a series of acute and chronic behaviors such as dieting, bulimic symptoms, and compulsive exercise (Fanjul-Peyró \& González-Oñate, 2011; Record \& Austin, 2016; Zancu \& Enea, 2016).

It has been reported that models are under social pressure (e.g., family, relatives, media, peers) to achieve an idealized body, which affects their body image perception (Saüch \& Castañer, 2013). The body image is defined as the internal representation of one's external appearance, a 
multidimensional construct including affective, cognitive, behavioral, and perceptual components (Altabe \& Thompson, 1993; Hausenblas \& Symons, 2001; Thompson, Heinberg, Altabe \& Tantleff- Dunn, 1999). Evidence suggests that at least $40 \%$ of the US population shows body image dissatisfaction, including fashion models (Dwyer, 2004; Swami \& Szmigielska, 2013; Yamamiya, Cash, Melnyk, Posavac, \& Posavac, 2005).

Body image dissatisfaction is related to low self-esteem, depression, eating disorders, and even suicide (Preti, Usai, Miotto, Petretto, \& Masala, 2008; Thompson \& Cafri, 2007). Metaanalytical evidence consistently found that physically active individuals, including athletes, have lower body dissatisfaction than their sedentary counterparts (Campbell \& Hausenblas, 2009; Hausenblas \& Fallon, 2006; Hausenblas \& Symons-Downs, 2001; Reel et al., 2007).

The vast majority of literature related to fashion models has been published with data from European and US samples. However, there is null information regarding body composition, physical activity, and body image among Central American models. Therefore, the aim of the study was to determine the association between body composition, physical activity, and body image among Costa Rican models and controls.

\section{Methods}

\section{Participants}

Male and female models and their respective controls participated in this study. Thus, fiftythree female $\left(\mathrm{n}=35, M_{\text {age }}=23.5 ; S D=5.2 \mathrm{yr}\right.$. $)$ and male $\left(\mathrm{n}=18, M_{\text {age }}=24.8 ; S D=4.7 \mathrm{yr}\right.$. $)$ models were compared to eighty-two female $\left(\mathrm{n}=40, M_{\text {age }}=21.5 ; S D=3.2 \mathrm{yr}\right.$.) and male ( $\mathrm{n}=$ $42, M_{\text {age }}=23.0 ; S D=3.3$ yr.) controls. Volunteers were recruited from modeling agencies, electronic social networks (e.g., Facebook), a newspaper post, and by participants' word-ofmouth. These strategies were used given a groundless negative perception regarding research on models. Participants were eligible to enter the study if they were between the ages of 18 and 35 , worked either as professional or part-time models, and had appearances in the media (e.g., television, magazines, printed and online news), and/or live-shows (e.g., beauty contests, fashion runways, special events).

\section{Measurement instruments}

Anthropometry and body composition assessment. Body height was determined by stadiometry (Novel Products Inc., Rockton, IL, USA) and body mass by an electronic scale (Tanita, model BF-350, Arlington Heights, IL, USA). The BMD and body fat percentage (BF\%) for each participant were determined by a DXA scan with software enCore 2011, version \# 13,60,033 (Lunar Prodigy Advance, General Electric, Madison, WI, USA).

Physical activity and body image assessment. PA was assessed with the short-version of the International Physical Activity Questionnaire (The IPAQ Group). This instrument has been previously used in a Costa Rican sample (Castillo-Hernández \& Moncada-Jiménez, 2010) and consists of seven items from which energy expenditure is estimated in MET-min/week. Body image (BI) was assessed with figure scales, one for females (Furnham, Titman, \& Sleeman, 
1994) and another for males (Hildebrandt, Langenbucher, \& Schlundt, 2004). The female BI scale shows nine female figures varying in muscularity from very thin to very muscular and has reported acceptable content evidence and test re-test reliability $(\mathrm{r}=0.84)$ (Cafri \& Thompson, 2004). The male BI scale shows 30 male figures varying in adiposity and muscularity dimensions, and reported convergent and divergent validity evidence as well as acceptable oneweek apart test re-test reliability $(r=0.72$ to 0.96$)$ (Hildebrandt et al., 2004). For both measurement instruments, participants were required to rate the figure that most resembled them (i.e., actual or current) and the figure they wanted to look like (i.e., desired or future). BI satisfaction (or dissatisfaction) was computed as the difference $(\Delta)$ between actual minus desired BI. A negative $\Delta$ means that the person wanted to look more muscular or bigger, while a positive $\Delta$ indicated that the person wanted to look slimmer.

\section{Procedures}

All procedures followed were in accordance with the ethical standards of the responsible revision committee on human experimentation of the University of Costa Rica and with the Helsinki Declaration of 1975. Informed consent was obtained from all participants included in the study. After reading and signing the informed consent to participate in the study, volunteers were assessed at the Human Movement Sciences Research Center. Firstly, participants completed the written questionnaires in a quiet room. Secondly, volunteers were instructed to remove any metal and jewelry from their persons and to wear shorts and a T-shirt. Then, participants were asked to stand on the stadiometer, barefoot with the head, back, buttocks and legs against the wall and feet at $60^{\circ}$. After this, participants were asked to take a deep breath and height was recorded to the nearest $0.5 \mathrm{~cm}$ (American College of Sports Medicine, 2010, 2014). Following this procedure, participants were asked to step onto the body mass scale and stay still while body weight $(\mathrm{kg})$ was read and recorded to the nearest $0.1 \mathrm{~kg}$. BMI was computed from these measurements. Finally, participants, lying in supine position, were scanned by DXA. Full-body scans were performed and analyzed by the same trained operator, and to ensure data quality the equipment was calibrated daily using a known calibration standard following manufacturer instructions and current quality control recommendations (Nana et al., 2015).

\section{Statistical analysis}

Statistical analysis was performed with IBM-SPSS Statistics, version 20 (IBM Corporation, Armonk, New York). Values are presented as mean and standard deviations $(M \pm S D)$ for the continuous dependent variables body height and weight, BMI, BMD, BF\%, PA and BI. Twoway group (models, controls) by gender (female, male) analyses of variance (ANOVA) were used to determine global differences in dependent variables. Independent samples t-tests were used to compare BI between genders and groups. Bivariate Pearson-product moment correlations between $\mathrm{BF} \%, \mathrm{PA}, \mathrm{BMD}$, and $\mathrm{BI}$ were calculated. Statistical significance for all tests was set $a$ priori at $p \leq 0.05$. 


\section{Results}

Descriptive statistics for all participants $(n=135)$ are presented in Table 1. ANOVA tests showed that models were taller than controls $(170.4 \pm 0.9$ vs. $166.6 \pm 0.7 \mathrm{~cm} ; p=0.002)$ and males were taller than females (175.4 \pm 0.9 vs. $161.64 \pm 0.75 \mathrm{~cm} ; p \leq 0.001)$. Male models had higher body weight than female models $(p \leq 0.001)$, and control males had higher body weight than female controls $(p \leq 0.001)$. Female models showed a lower BMI than female controls $(p$ $\leq 0.001)$, and a similar BMI was found between model and control males $(p=0.696)$. The $\mathrm{BF} \%$ was lower in models than controls $(21.7 \pm 1.0$ vs. $26.2 \pm 0.7 \% ; p \leq 0.001)$, and $\mathrm{BF} \%$ was lower in males than females $(16.5 \pm 0.9$ vs. $31.4 \pm 0.8 \% ; p \leq 0.001)$. BMD was higher in models than controls $\left(1.18 \pm 0.12\right.$ vs. $\left.1.17 \pm 0.01 \mathrm{~g} / \mathrm{cm}^{2} ; p \leq 0.001\right)$.

Table 1. Descriptive statistics for female and male models and controls $(n=135)$.

\begin{tabular}{lcccc}
\hline & \multicolumn{2}{c}{ Females $(\mathbf{n}=\mathbf{7 5})$} & \multicolumn{2}{c}{ Males $(\mathbf{n}=\mathbf{6 0})$} \\
\cline { 2 - 5 } Variable & $\begin{array}{l}\text { Models } \\
(\mathbf{n}=\mathbf{3 5})\end{array}$ & $\begin{array}{c}\text { Controls } \\
(\mathbf{n}=\mathbf{4 0})\end{array}$ & $\begin{array}{l}\text { Models } \\
(\mathbf{n}=\mathbf{1 8})\end{array}$ & $\begin{array}{c}\text { Controls } \\
(\mathbf{n}=\mathbf{4 2})\end{array}$ \\
\hline Age $(\mathrm{yr})$. & $23.5 \pm 5.2$ & $21.5 \pm 3.2$ & $24.8 \pm 4.7$ & $23.0 \pm 3.3$ \\
Height $(\mathrm{cm})$ & $163.3 \pm 5.0$ & $156.9 \pm 7.0$ & $177.5 \pm 6.4$ & $173.3 \pm 6.9$ \\
Weight $(\mathrm{kg})$ & $55.4 \pm 4.8$ & $58.1 \pm 9.1$ & $75.4 \pm 8.8$ & $71.2 \pm 9.3$ \\
BMI $\left(\mathrm{kg} / \mathrm{m}^{2}\right)$ & $20.8 \pm 1.7$ & $22.7 \pm 2.9$ & $23.9 \pm 2.5$ & $23.7 \pm 2.3$ \\
BF $(\%)$ & $28.6 \pm 6.8$ & $34.2 \pm 7.0$ & $14.9 \pm 6.5$ & $18.2 \pm 6.3$ \\
BMD $\left(\mathrm{g} / \mathrm{cm}^{2}\right)$ & $1.1 \pm 0.1$ & $1.1 \pm 0.1$ & $1.2 \pm 0.1$ & $1.2 \pm 0.1$ \\
\hline
\end{tabular}

Note: $\mathrm{BMI}=$ Body mass index, $\mathrm{BF}=$ Body fat mass, $\mathrm{BMD}=$ Bone mineral density

The ANOVA test showed no significant interaction in total weekly PA for male and female models and controls $(p=0.627)$. A significant main effect indicates that regardless of the group (i.e., models, controls), males reported higher mean weekly PA levels than females (5771.27 \pm 473.57 vs. $3626.93 \pm 389.01$ MET-min/week; $p=0.001$ ) (Figure 1). Participants were classified based on their weekly PA according to the IPAQ algorithm as having either low, moderate or high PA levels (Figure 2). 


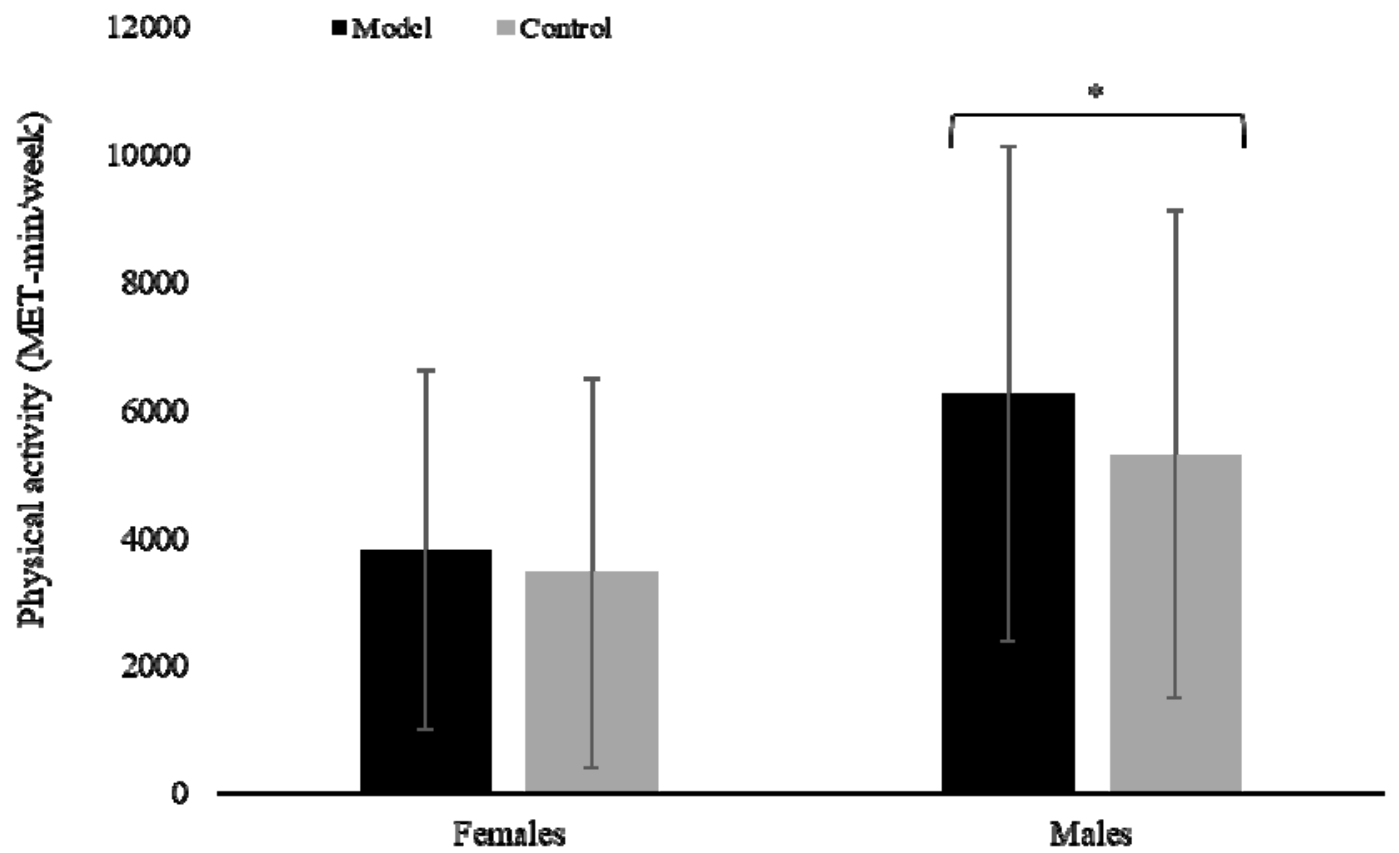

* $p=0.001$, all males $>$ all females

Figure 1. Weekly physical activity levels in male and female models and controls $(n=135)$.

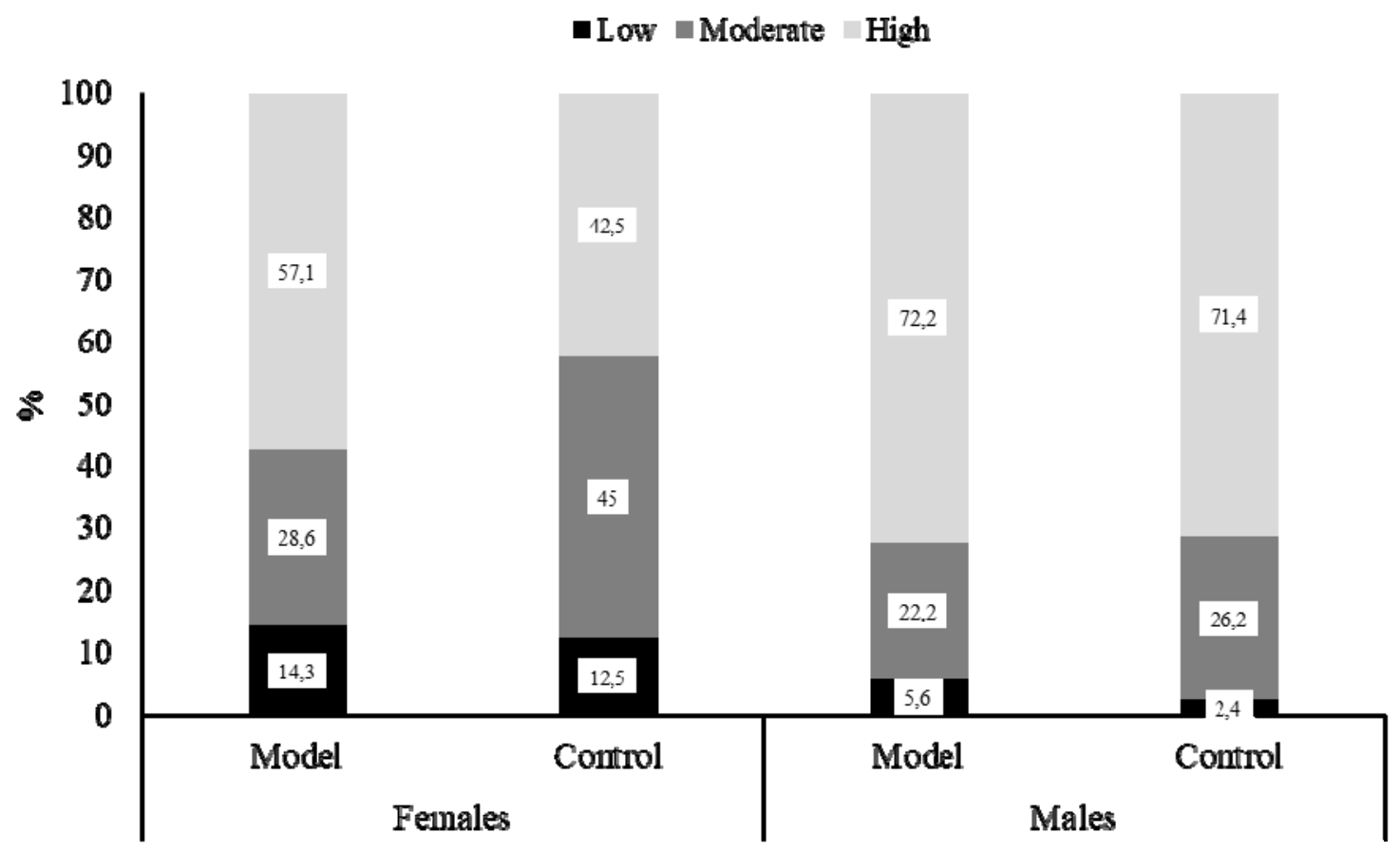

Figure 2. Categorical physical activity levels (i.e., low, moderate and high) by group and gender $(n=135)$. 
For all participants $(\mathrm{n}=135)$, significant correlations were found between weekly PA and $\mathrm{BF} \%$ $(\mathrm{r}=-0.38, p \leq 0.001$, Figure 3a), between weekly PA and BMD $(\mathrm{r}=0.31, p \leq 0.001$, Figure $3 \mathrm{~b})$. Also, a significant correlation was found between BMD and $\mathrm{BF} \%(\mathrm{r}=-0.44, p \leq 0.001)$. Regardless of the group (i.e., models, controls), a significant correlation was found between weekly PA and $\mathrm{BF} \%$ in females $(\mathrm{r}=-0.26, p=0.023)$ and males $(\mathrm{r}=-0.27, p=0.039)$. In addition, regardless of gender, a significant correlation was found between weekly PA and $\mathrm{BF} \%$ in models $(\mathrm{r}=-0.50, p \leq 0.001)$ and controls $(\mathrm{r}=-0.31, p=0.005)$.

No significant differences were found in BI dissatisfaction between females (models $\Delta=-1.31$ \pm 0.93 vs. controls $\Delta=-1.05 \pm 1.26, p=0.307$ ) or males on the BI adiposity dimension dissatisfaction (models $\Delta=12.22 \pm 17.00$ vs. controls $\Delta=14.00 \pm 13.34 ; p=0.674$ ) and the BI muscularity dimension dissatisfaction (models $\Delta=11.11 \pm 10.23$ vs. controls $\Delta=14.00 \pm$ $10.33 ; p=0.327)$.

For all males $(\mathrm{n}=60)$, there was a significant correlation between BMD and the BI muscularity dimension dissatisfaction $(\mathrm{r}=-0.33, p=0.012)$. No significant correlations were found between weekly PA and BI dissatisfaction in females $(-0.01, p=0.930)$, and between weekly PA and the BI adiposity and muscularity dimensions dissatisfaction in males $(\mathrm{r}=-0.04, p=$ 0.759 and $\mathrm{r}=0.01, p=0.921$, respectively). Specifically, for female models, no significant correlations were found between BMD and weekly PA $(\mathrm{r}=0.26, p=0.135)$, BMD and BI dissatisfaction $(\mathrm{r}=0.12, p=0.481)$, and weekly PA and $\mathrm{BI}$ dissatisfaction $(\mathrm{r}=-0.01, p=$ 0.937). For female controls, no significant correlations were found between BMD and weekly PA $(\mathrm{r}=0.08, p=0.623)$, BMD and BI dissatisfaction $(\mathrm{r}=0.09, p=0.605)$, and weekly PA and BI dissatisfaction $(\mathrm{r}=0.00, p=0.994)$.

For male models, no significant correlations were found between BMD and weekly PA $(\mathrm{r}=$ $0.26, p=0.308)$, BMD and the $\mathrm{BI}$ adiposity dimension dissatisfaction $(\mathrm{r}=-0.10, p=0.688)$, weekly PA and the $\mathrm{BI}$ adiposity dimension dissatisfaction $(\mathrm{r}=0.08, p=0.759)$, and weekly PA and the $\mathrm{BI}$ muscular dimension dissatisfaction $(\mathrm{r}=0.08, p=0.767)$. A significant correlation was found between BMD and the BI muscular dimension dissatisfaction $(\mathrm{r}=-0.52, p=0.029)$. For male controls, no significant correlations were found between BMD and weekly PA $(\mathrm{r}=$ $0.19, p=0.225)$, BMD and the $\mathrm{BI}$ adiposity dimension dissatisfaction $(\mathrm{r}=0.14, p=0.379)$, and $\mathrm{BMD}$ and the $\mathrm{BI}$ muscularity dimension dissatisfaction $(\mathrm{r}=-0.25, p=0.120)$. In addition, no significant correlations were found between weekly PA and the BI adiposity dimension dissatisfaction $(\mathrm{r}=-0.09, p=0.566)$, and weekly PA and the $\mathrm{BI}$ muscular dimension dissatisfaction $(\mathrm{r}=0.00, p=0.963)$. 

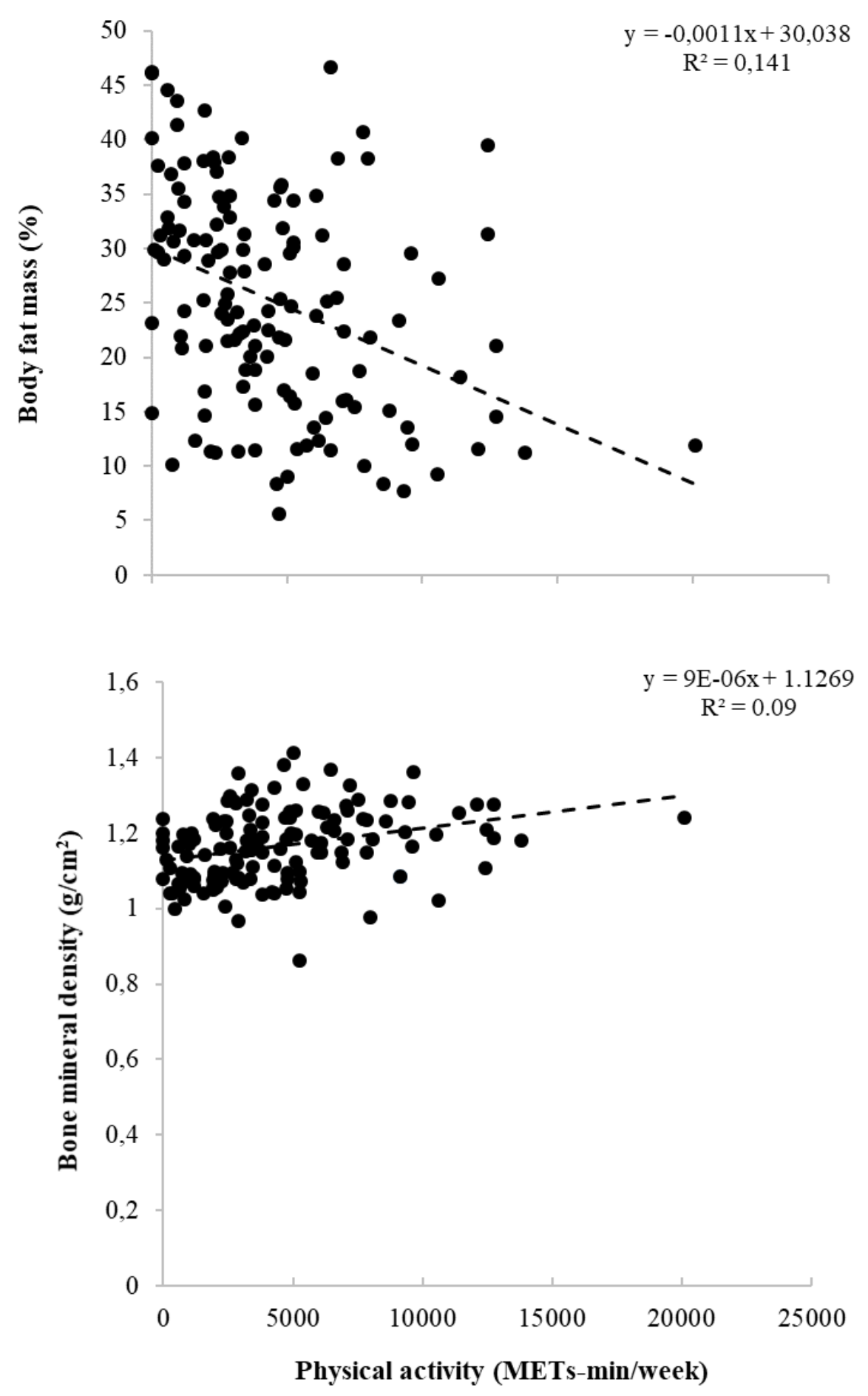

Figure 3. Scatter plots for the association between physical activity, body fat mass (\%) and bone mineral density for all participants $(n=135)$.

\section{Discussion}

This is the first study undertaken in Central America to determine the association between body composition, physical activity and body image among models and controls. Anthropometric (c) Psy, Soc, \& Educ, 2019, Vol. 11(2) 
analyses showed expected gender differences such as males being taller and heavier than females (Stewart \& Sutton, 2012). Regardless of gender, models were taller, heavier and had higher BMD than controls. These differences are likely explained by a lower BF\%, and consequently, a higher lean tissue body mass (Heymsfield, Lohman, Wang, \& Going, 2005). The differences in BMD are unlikely explained only by PA since BMD is also related, among other variables, to income and micro- and macronutrient intake from the diet (Kabagambe, Baylin, Siles, \& Campos, 2002), variables not recorded in this study. Besides, PA was similar between male models and controls and between female models and controls.

Previous evidence has shown that models had lower BMI than controls (Swami \& Szmigielska, 2013; Zancu \& Enea, 2016). According to the American College of Sports Medicine (2014), the mean BMI of the participants on the present study was within the normal healthy range $\left(18.5-24.9 \mathrm{~kg} / \mathrm{m}^{2}\right)$. However, $14.3 \%$ of female models and $2.5 \%$ of female controls showed BMI values below $18.5 \mathrm{~kg} / \mathrm{m}^{2}$, considered low weight for their height. These BMI figures are lower than values previously reported for professional models (50\%-54.5\%) and controls (8.2\%-12.7\%) (Preti et al., 2008; Swami \& Szmigielska, 2013). No data is available for male models, a group highly under-reported in the literature. A low BMI score has been related to increased risk for future fracture (especially in the hip), low BMD, increased bone loss, and recently, to poor psychological well-being, including dementia (Berlinger \& Potter, 1991; De Laet et al., 2005; Liu et al., 2015; Ravn et al., 1999). However, in this study models had higher BMD than controls; therefore, more research on the association between these variables is required.

In this study, males reported being more physically active than females, a trend clearly reported in the literature from early childhood to adulthood (Colley et al., 2011; Frömel, Stelzer, Groffik, \& Ernest, 2008). As mentioned before, no differences in PA were obtained among male or female models and controls. This area deserves further inquiry since tabloids suggest that top models workout and follow other healthy lifestyle patterns (Bourne, 2013; Held, 2013). Therefore, assessment tools are needed to properly track PA behavior and energy intake (i.e., food consumption) in this working group.

No significant differences were found on BI dissatisfaction between female models and controls. This suggests that adiposity and muscularity perceptions were similar between this group of models and controls. These findings are consistent with previous studies that have reported no significant differences on BI dissatisfaction between female models and controls (Brenner \& Cunningham; Preti et al., 2008; Swami \& Szmigielska, 2013). However, in spite of the lack of differences on BI satisfaction among female models and controls, it is emphasized that on average all females showed some degree of dissatisfaction with their physical appearance, which might be interpreted to mean that all wanted to look more muscular. This finding supports previous evidence showing not only that in general females show some degree of dissatisfaction with their body (Castillo-Hernández \& Moncada-Jiménez, 2015; Sohn, 2009), but also their current struggle for being in better muscular and physical shape (Tiggemann \& Zaccardo, 2015; Vogel, 2015). There is a lack of information on BI dissatisfaction in male models, which deserves further study. 
In this study, significantly lower BF\% and increased BMD were observed among participants reporting higher levels of weekly PA. In addition, participants with higher BMD also showed lower BF\%, a finding previously reported in males (Kang et al., 2014). Increased levels of PA and a reduction of sedentary time are consistently related to improved bone health as measured in different bone sites (Chastin, Mandrichenko, Helbostadt, \& Skelton, 2014), as well as a reduced $\mathrm{BF} \%$ in a dose-dependent manner (Golubic et al., 2015).

For female models and controls, no significant correlations were found between weekly PA and BI dissatisfaction. Similarly, for male models and controls, no significant correlations were found between weekly PA and the BI dissatisfaction on the adiposity and muscular dimensions. These findings suggest that our participants had a positive BI perception regardless of their PA levels. In the general population, the evidence suggests that increased PA levels are inversely related to BI dissatisfaction (Campbell \& Hausenblas, 2009; Hausenblas \& Fallon, 2006; Hausenblas \& Symons-Downs, 2001; Reel et al., 2007).

The present study had methodological limitations. We attempted to recruit models in several modeling agencies by telephone and e-mail from their personal websites and social media. We also contacted locally recognized models to ask for their help; however, they did not participate because they were busy or not interested. In some cases, they did not reply to our messages. Others previously described this recruitment problem (Preti et al., 2008); however, we gave our best effort to explain the tests and measures we wanted to perform. For those models who answered our calls, we observed a positive attitude towards the information provided following the body composition assessment. Indeed, they helped us to recruit more of their peers, which might have also likely resulted in selection biases that limit the generalizability of our findings. In addition, the sample was restricted to individuals residing in the Costa Rican Central Valley, between the ages of 18 and 35 years, which limits generalizability. Yet, the sample size used in this study is comparable to other studies performed in larger and more populated countries.

In conclusion, Costa Rican models were taller and had lower $\mathrm{BF} \%$ and higher $\mathrm{BMD}$ than controls. Males were more physically active than females and BI was similar between genders and groups. More studies are needed to better describe other Central American models, as well as their perceptions on several psychosocial constructs related to body image, sedentary behavior, and energy intake and expenditure, among others.

\section{References}

American College of Sports Medicine. (2010). ACSM's health-related physical fitness assessment manual ( $3^{\text {rd }}$ ed.). Philadelphia, PA.: Wolters Kluwer, Lippincott Williams \& Wilkins.

American College of Sports Medicine. (2014). ACSM's Guidelines for Exercise Testing and Prescription $\left(9^{\text {th }}\right.$ ed.). Philadelphia, PA.: Wolters Kluwer, Lippincott Williams \& Wilkins.

Berlinger, W. G., \& Potter, J. F. (1991). Low Body Mass Index in demented outpatients. J Am Geriatr Soc, 39(10), 973-978. 
Bourne, L. (2013). 6 Victoria's Secret angels spill their diet and exercise secrets. Retrieved from http://stylecaster.com/victorias-secret-angels-diet-and-exercise-secrets/

Brenner, J. B., \& Cunningham, J. G. Gender differences in eating attitudes, body concept, and self-esteem among models. Sex Roles, 27(7), 413-437. doi:10.1007/bf00289949

Cafri, G., \& Thompson, J. K. (2004). Evaluating the convergence of muscle appearance attitude measures. Assessment, 11(3), 224-229. doi:10.1177/1073191104267652

Campbell, A., \& Hausenblas, H. A. (2009). Effects of Exercise Interventions on Body Image A Meta-analysis. Journal of health psychology, 14(6), 780-793.

Castillo-Hernández, I., \& Moncada-Jiménez, J. (2010). The effect of the frequency of participation in a resistance training exercise program on the esteem and body satisfaction of Costa Rican college women. Revista Iberoamericana de Psicología del Ejercicio y el Deporte, 5(2), 195-212.

Castillo-Hernández, I., \& Moncada-Jiménez, J. (2015). Los espejos no afectan de manera crónica variables psicológicas en mujeres que realizan un programa de entrenamiento contra resistencia o actividades pasivas (Mirrors do not Chronically Affect Psychological Variables in Women Participating in a Resistance-Training Programme or in passive activities). Apunts: Educacion Fisica y Deportes(121), 80-87.

Cline, E. (2013). Fashion models are workers, too. Nation, 297(13), 18-21.

Colley, R. C., Garriguet, D., Janssen, I., Craig, C. L., Clarke, J., \& Tremblay, M. S. (2011). Physical activity of Canadian adults: accelerometer results from the 2007 to 2009 Canadian Health Measures Survey. Ottawa, Canada: Statistics Canada.

Chastin, S. F., Mandrichenko, O., Helbostadt, J. L., \& Skelton, D. A. (2014). Associations between objectively-measured sedentary behaviour and physical activity with bone mineral density in adults and older adults, the NHANES study. Bone, 64, 254-262. doi:10.1016/j.bone.2014.04.009

De Laet, C., Kanis, J. A., Oden, A., Johanson, H., Johnell, O., Delmas, P., . . Tenenhouse, A. (2005). Body mass index as a predictor of fracture risk: a meta-analysis. Osteoporos Int, 16(11), 1330-1338. doi:10.1007/s00198-005-1863-y

Dwyer, A. (2004). Disorder or delight? Towards a new account of the fashion model body. Fashion Theory: The Journal of Dress, Body \& Culture, 8(4), 405-423.

Ekelund, U., Besson, H., Luan, J., May, A. M., Sharp, S. J., Brage, S., . . Peeters, P. H. (2011). Physical activity and gain in abdominal adiposity and body weight: prospective cohort study in 288,498 men and women. Am J Clin Nutr, 93(4), 826-835. doi:10.3945/ajen.110.006593

Fanjul-Peyró, C., \& González-Oñate, C. (2011). La influencia de modelos somáticos publicitarios en la vigorexia masculina: un estudio experimental en adolescentes (The influence of somatic advertising models on male vigorexia: an experimental study in adolescents). Zer, 16(31), 265-284.

Frömel, K., Stelzer, J., Groffik, D., \& Ernest, J. (2008). Physical Activity of Children Ages 68: The Beginning of School Attendance. Journal of Research in Childhood Education, 23(1), 29-40. doi:10.1080/02568540809594644

Furnham, A., Titman, P., \& Sleeman, E. (1994). Perception of female body shapes as a function of exercise. Journal of Social Behavior \& Personality, 9(2), 335-352. 
Garber, C. E., Blissmer, B., Deschenes, M. R., Franklin, B. A., Lamonte, M. J., Lee, I. M., . . Swain, D. P. (2011). American College of Sports Medicine position stand. Quantity and quality of exercise for developing and maintaining cardiorespiratory, musculoskeletal, and neuromotor fitness in apparently healthy adults: guidance for prescribing exercise. Med Sci Sports Exerc, 43(7), 1334-1359. doi:10.1249/MSS.0b013e318213fefb

Golubic, R., Wijndaele, K., Sharp, S. J., Simmons, R. K., Griffin, S. J., Wareham, N. J., . . . Brage, S. (2015). Physical activity, sedentary time and gain in overall and central body fat: 7-year follow-up of the ProActive trial cohort. Int J Obes (Lond), 39(1), 142-148. doi:10.1038/ijo.2014.66

Hausenblas, H. A., \& Fallon, E. A. (2006). Exercise and body image: A meta-analysis. Psychology and Health, 21(1), 33-47.

Hausenblas, H. A., \& Symons-Downs, D. (2001). Comparison of body image between athletes and nonathletes: A meta-analytic review. Journal of Applied Sport Psychology, 13(3), 323-339.

Held, L. E. (2013). The workout habits of 7 top models. Retrieved from http://wellandgood.com/2013/11/18/the-workout-habits-of-7-top-models/

Heymsfield, S., Lohman, T., Wang, Z. M., \& Going, S. (2005). Human Body Composition $\left(2^{\text {nd }}\right.$ ed.). Champaign, IL: Human Kinetics.

Hildebrandt, T., Langenbucher, J., \& Schlundt, D. G. (2004). Muscularity concerns among men: development of attitudinal and perceptual measures. Body Image, 1(2), 169-181. doi:10.1016/j.bodyim.2004.01.001

Kabagambe, E. K., Baylin, A., Siles, X., \& Campos, H. (2002). Comparison of dietary intakes of micro- and macronutrients in rural, suburban and urban populations in Costa Rica. Public Health Nutr, 5(6A), 835-842. doi:10.1079/phn2002372

Kang, D., Liu, Z., Wang, Y., Zhang, H., Feng, X., Cao, W., \& Wang, P. (2014). Relationship of body composition with bone mineral density in northern Chinese men by body mass index levels. J Endocrinol Invest, 37(4), 359-367. doi:10.1007/s40618-013-0037-6

Kim, K., \& Sagas, M. (2014). Athletic or Sexy? A Comparison of Female Athletes and Fashion Models in Sports Illustrated Swimsuit Issues. Gender Issues, 31(2), 123-141. doi:10.1007/s12147-014-9121-2

Kremers, H. M., Nicola, P. J., Crowson, C. S., Ballman, K. V., \& Gabriel, S. E. (2004). Prognostic importance of low body mass index in relation to cardiovascular mortality in rheumatoid arthritis. Arthritis \& rheumatism, 50(11), 3450-3457.

Liu, Z., Huang, J., Qian, D., Chen, F., Xu, J., Li, S., . . Wang, X. (2015). Does low body mass index matter? Relationship between body mass index and subjective well-being among long-lived women over 95 years of age. The journal of nutrition, health \& aging, 1-7. doi:10.1007/s12603-015-0556-2

Nana, A., Slater, G. J., Stewart, A. D., \& Burke, L. M. (2015). Methodology review: using dual-energy X-ray absorptiometry (DXA) for the assessment of body composition in athletes and active people. Int $J$ Sport Nutr Exerc Metab, 25(2), 198-215. doi:10.1123/ijsnem.2013-0228

Preti, A., Usai, A., Miotto, P., Petretto, D. R., \& Masala, C. (2008). Eating disorders among professional fashion models. Psychiatry Research, 159(1-2), 86-94. doi:10.1016/j.psychres.2005.07.040 
Ravn, P., Cizza, G., Bjarnason, N. H., Thompson, D., Daley, M., Wasnich, R. D., . . . Christiansen, C. (1999). Low Body Mass Index is an important risk factor for low bone mass and increased bone loss in early postmenopausal women. Journal of Bone and Mineral Research, 14(9), 1622-1627. doi:10.1359/jbmr.1999.14.9.1622

Record, K. L., \& Austin, S. B. (2016). "Paris Thin": A Call to Regulate Life-Threatening Starvation of Runway Models in the US Fashion Industry. American Journal of Public Health, 106(2), 205-206.

Reel, J. J., Greenleaf, C., Baker, W. K., Aragon, S., Bishop, D., Cachaper, C., . . Hattie, J. (2007). Relations of body concerns and exercise behavior: a meta-analysis. Psychol Rep, 101(3 Pt 1), 927-942. doi:10.2466/pr0.101.3.927-942

Saüch, G., \& Castañer, M. (2013). The projection of body image in young adults and seniors. A specific application of expression of corporeality. Retos, 24, 113-116.

Sohn, S. H. (2009). Body image: Impacts of media channels on men's and women's social comparison process, and testing of involvement measurement. Atlantic Journal of Communication, 17(1), 19-35. doi:10.1080/15456870802505670

Stableford, D. (2012). Israel's skinny model ban: New law requires body mass index of 18.5 or a doctor's note. Retrieved from http://news.yahoo.com/blogs/cutline/israel-skinnymodel-ban-law-requires-body-mass-160408015.html

Stewart, A. D., \& Sutton, L. (2012). Body Composition in Sport, Exercise and Health. Oxon, UK: Routledge.

Swami, V., \& Szmigielska, E. (2013). Body image concerns in professional fashion models: Are they really an at-risk group? Psychiatry Research, 207(1), 113-117. doi:10.1016/j.psychres.2012.09.009

The IPAQ Group. (2005). Guidelines for the data processing and analysis of the "International Physical Activity Questionnaire". Retrieved from https://sites.google.com/site/theipaq/scoring-protocol

Thompson, J. K., \& Cafri, G. (2007). The muscular ideal: Psychological, social, and medical perspectives. Washington, DC: American Psychological Association.

Tiggemann, M., \& Zaccardo, M. (2015). "Exercise to be fit, not skinny": The effect of fitspiration imagery on women's body image. Body Image, 15, 61-67. doi:10.1016/j.bodyim.2015.06.003

Vogel, A. (2015). Social Media, and Body Image: Complicated Relationship. IDEA Fitness Journal, 12(1), 39-44.

Yamamiya, Y., Cash, T. F., Melnyk, S. E., Posavac, H. D., \& Posavac, S. S. (2005). Women's exposure to thin-and-beautiful media images: body image effects of media-ideal internalization and impact-reduction interventions. Body Image, 2(1), 74-80. doi:http://dx.doi.org/10.1016/j.bodyim.2004.11.001

Zancu, S. A., \& Enea, V. (2016). Eating disorders among fashion models: a systematic review of the literature. Eat Weight Disord, 22(3), 395-405. doi:10.1007/s40519-016-0293-5 